\title{
Patchwork vs. Proactive Social Protection Policies: CCTs and Social Expenditure in Brazil and the Philippines*
}

\author{
MARK STEVENSON CURRY**
}

\begin{abstract}
Conditional Cash Transfer (CCT) programs disburse cash grants to targeted recipient families under requirements for education and maternal health. These programs have been widely adopted with international donor assistance since the 1990s. Most CCT research examines program effectiveness at the demand level-the cash provision and compliance outcomes. This paper considers the respective supply-side question of health and education budgeting in Brazil and the Philippines during the relevant period of CCT implementation. The data provide that whereas Brazil has improved such access to services to complement its CCT programs, the Philippines has underinvested in supply-side provision. Brazil thus exhibits an integrated conceptualization of social protection for development. The Philippines exhibits a patchwork scheme for short term goals.
\end{abstract}

Keywords: CCTs, Social Protection, Brazil, Philippines, Budgets, Health, Education

The author would like to acknowledge the substantial contributions of Airah T. Cadiogan to this paper. Also to be thanked are Greg Robinson, Alex Moore, Mikyung Park and Teresa Tamayo. The inputs of the anonymous reviewers and the ISR editorial staff are greatly appreciated.

** Assistant professor, De La Salle University, Manila, Philippines;

E-mail: curry.mark@gmail.com;

DOI: 10.16934/isr.15.2.201412.25 


\section{INTRODUCTION}

Conditional Cash Transfer (CCT) programs involve the disbursement of cash grants directly to poor beneficiary households, provided that parents comply with requirements related to improving the health and education of young children and the health of pregnant mothers. First implemented in Latin America in the 1990s, CCT programs have been an integral part of a set of economic reforms designed to respond to the widening income gap and economic turmoil caused by structural adjustment in countries like Mexico and Brazil (Holzmann et al. 2003). Since then, CCT programs have been widely promoted based on their potential to arrest intergenerational poverty and facilitate achievement of Millennium Development Goals (MDGs) (Britto 2005; Fajth and Vinay 2010). Today, virtually every country in Latin America and the Caribbean, along with pilot countries in Southeast Asia and Africa, are implementing a version of CCT involving the assistance of international lenders (see Fiszbein and Schady 2009).

However, unlike CCT programs first implemented by Latin American governments, CCT programs supported by the World Bank in Asia and Africa have presented ample room for "distorted readings" (Dreze and Sen 2011, 10) by functioning merely as "add-on" social protection programs in support of prevailing neoliberal economic policies (Elson 2004; Britto 2005). Rather than reworking unfair economic policies, these CCT programs reinforce them by providing shorttem reprieve (Elson 2004, 64, as cited in Bradshaw 2008, 189).

In this light, it is increasingly imperative to understand how different CCT programs fit into a country's social protection strategy and overarching social policies, particularly those relating to funding public health and education. This is a necessary first step to analyze whether and to what extent CCT programs are treated as add-on social protection programs or as integral components of a social protection strategy (Cook and Kabeer 2009; Dreze and Sen 2011). This paper aims to do that by examining Brazil's Bolsa Familia and the Philippines' Pantawid Pamilyang Pilipino Program (Pantawid) CCT programs alongside national social policies that support or complement them. Do they function as important components of an integrated national social protection strategy or are they are standalone social protection programs? What, in turn, does such analysis add towards an understanding of development strategies and aims in countries such as Brazil and the Philippines?

\section{CCTs and Social Policy in the Philippines and Brazil}

The Pantawid Pamilyang Pilipino Program (Pantawid) was first implemented in 2007 under the auspices of the World Bank and Australian Aid. Its design was based on the achievements of CCT programs in Latin America, specifically that of 
Brazil's Bolsa Familia. ${ }^{1}$ As such, both have comparable objectives, designs, and monitoring and evaluation frameworks (see Curry, Cadiogan and Guigliano 2013). This is not the only basis for developing a comparison between the two countries' respective CCT programs. First, both countries experienced entrenched long-term colonial control under the administration of distant European powers. Second, in the $20^{\text {th }}$ Century, both countries were respectively governed for decades under dictatorships that ended with a return to democratic rule at roughly the same time (1986 in the Philippine case; 1985 in Brazil's). And as a result of the democratic shift, both countries established new constitutions that enshrined and prioritized universal rights regarding citizenship, thus establishing a new focus for social policy centered on inclusiveness and access.

Of specific relevance to this paper, the constitutions of Brazil and the Philippines each recognize people's right to affordable and high-quality education and healthcare. In addition, for Brazil, the idea of a citizen's "right to social security" included in its 1988 Constitution is said to have paved the way for Bolsa Familia and other social protection programs that preceded it (e.g., Bolsa Ecola, Fome Zero) (Britto 2005). In the case of the Philippines, there is no evidence to suggest that constitutional provisions that protect people's right to affordable health care and quality education exerted any direct influence on the design and implementtation of Pantawid. Instead, policy documents show that it was the Philippine government's desire to meet the MDGs on poverty reduction (Goal 1), maternal health (Goal 5), and education (Goal 2) that motivated it to pursue CCT programs (DSWD 2009a).

These distinctions in policy contexts are extremely important for discussions on the success of CCT programs like Bolsa Familia. At the minimum, they reveal key philosophical and ideological differences that drive different CCT programs in countries like Brazil and the Philippines. They illustrate how each state understands its role in providing social services and realizing human development through various interventions, such as CCT programs.

Despite these differences, the discourses employed by the governments and development institutions to justify CCT programs are consistently the same: stop intergenerational poverty; enhance human capabilities of the poor; and invest in human capital. However, for this vision to be realized, the provision of essential goods and services cannot be neglected (UNDP 2013). CCT programs can at best alleviate demand-side constraints on social services. There must be ongoing interventions to address supply-side shortages. Analyzing national social expenditures can thus address the question of state-led pro-active engagement in social protection.

To be clear: in Brazil and the Philippines, the budgets allotted to CCTs are the responsibility of the department or ministry of social development. This type of arrangement reflects the fact that CCTs address only the demand-side constraints 
of social protection. Supply-side constraints on health and education can only be addressed by sufficient budgetary allocations to the departments or ministries of health and education. The concern of this paper is not in relation to the total or proportional funds allotted to CCT programs or even to the outcomes of these initiatives. Instead, the enquiry followed here is whether and to what extent CCT programs in Brazil and the Philippines are being supplemented by supply-side provisions. This follows the argument that for CCT programs to work as envisaged, interventions from the state vis-à-vis health and education are necessary to achieve constructive human development.

\section{LITERATURE REVIEW}

\section{Cash Transfers as Social Policy}

As social policy, cash transfers (CTs) fall under the category of social assistance, which refers to programs involving transfers distributed to targeted beneficiary groups like the indigent, the disability and the elderly. Steven Tabor (2002, 1) defined CTs as "the provision of assistance in the form of cash to the poor" or to those who might fall into poverty without it.

In general, CTs may be employment-related (e.g., cash-for-work schemes, social pensions, unemployment or disability allowances), universal (e.g., universal health insurance), or means-tested (e.g., cash transfers for the poorest people); conditional or unconditional; long-term or short-term (Tabor 2002). CCT programs, as discussed in this paper, refer to cash transfer schemes that are means-tested, conditional, and implemented for a fixed period of time, for the purpose of reducing extreme poverty and improving income equality.

According to Anthony Hall (2007), the World Bank has three agendas behind their support for social policies, particularly CCTs: social welfare, social protection, and social development. Social welfare pertains to developing human capital to boost economic growth (improving educational attainment, health and nutrition standards, and controlling population); social protection relates to the establishment of social safety nets to protect the most vulnerable groups against external economic and environmental shocks; while social development concerns the advancement of the World Bank's development agenda of sustainable development, participatory development, good governance, and poverty reduction (Hall 2007). For the most part, however, Hall $(2007,153)$ observed that "social policy in the Bank is increasingly seen as being synonymous with social protection." One popular social protection measure among Bank staff and clients is CCT programs. Hall (2007, 158-160) attributed this narrow vision to two advantages that CCT programs have over other social policies: for the Bank, CCT programs are effective and cost-efficient in targeting the most vulnerable groups (women and children) 
(economic austerity); on the part of borrowing governments, CCT programs increase government revenues and are politically appealing to ruling parties (political expediency).

Jimi Adesina (2010) also noted that CCT programs have become the preferred social policy of the World Bank and among developing countries reliant on the Bank's support. The shift in social policy priorities across the developing world represented "a retreat into a narrow, diminutive version of social policy" (3). Importantly, it came at the expense of envisioning a broader, transformative social policy, of which social protection is supposed to be just one component. Moreover, Adesina emphasized the need to return to a vision "with emphasis on inter-sectoral linkages among policy instruments, rather than fragmentary thinking and singleissue policy-merchandizing" (16).

The 2013 Human Development Report raised important points concerning CCTs as a social policy implemented across the developing world. The report identified determined social policy innovation as one of the three drivers of social transformation among the Global South's best economic performers-namely, Brazil, India, China and South Africa. Social policy innovation includes increasing public investment in health and education, promoting inclusive and universal access to high-quality education and health care, and increasing social cohesion (UNDP 2013). The report singled out CCT programs as one of the innovative social protection policies that originated in the South and helped alleviate extreme poverty in Mexico and Brazil.

However, the 2013 HDR also quoted Turkey's minister of development who said that CCT programs, while effective in reducing extreme poverty and improving incomes, "cannot substitute for public provision of essential goods and services" (cited in UNDP 2013, 83). While CCT programs alleviate the demand-side constraints of social services, governments must do their part to address supply-side constraints like poor infrastructure and chronic shortages of schools, hospitals, well-trained doctors and medical personnel, and the overall poor quality of education and health care. The report emphasized "that substantial public investment effectively deployed not just in infrastructure, but also in health and education-is key to achieving and sustaining human development" (UNDP 2013, 77). In other words, governments should not rely solely on CCT programs to reduce poverty or produce development.

In terms of evaluating CCT programs, CCTs in general have been deemed successful in redistributing cash to increase basic consumption among the very poor in the short-term, while simultaneously and complementarily changing behavior and attitudes among beneficiaries for long-term human development (Rawlings and Rubio 2005). This is done through rationalizing the "social contract" of tying cash disbursements to social development requirements as a means to gain public and political support for the programs (Farrington et al. 2005; de Janvry et al. 2006; de la Brière and Rawlings 2006; Fiszbein and Schady 2009). CCT pro- 
grams in Latin America have reportedly succeeded in increasing school attendance/ completion and access to preventive healthcare; reducing severe poverty, rates of illness and overall vulnerability of beneficiaries; enhancing community social relations; and reaching target populations (efficiency component) (Britto 2005; de la Brière and Rawlings 2006).

Overall, CCT programs demonstrate effectiveness in meeting short-term needs of poor populations (see Vermehren 2003; Rawlings and Rubio 2005; de Janvry et al. 2006; Handa and Davis 2006; Bassett 2008; Lomelí 2008; Fiszbein and Schady 2009; Pacheco Santos et al. 2011). The area where they are not effective is in meeting long-term needs that are crucial to enhancing human capabilities and human development. This is not a missed opportunity-CCT programs are simply not designed to realize these goals. They were, instead, initially implemented only as part of an overall social policy that includes interventions on the supply side-that is, for example, building roads, schools, hospitals, and improving the quality of education and health care services. These interventions can only be realized when matched with increased and sustained public investment in social services. Apart from the 2013 HDR, no other publication to date has underscored this facet of CCT programs.

\section{STUDY FRAMEWORK}

The framework for this paper examines conditional cash transfer (CCT) programs based on the discourse employed by the proponents of the two programs under consideration-that is, the Philippines' Pantawid and Brazil's Bolsa Familia. This discourse is consistent with the Capability Approach to development, which views poverty as a multidimensional problem that can be addressed by enhancing human capabilities, as specifically listed in the Millennium Development Goals (MDGs). It draws mainly from Amartya Sen's capability approach, specifically the concepts of functionings and capabilities and how these are ostensibly realized through the provision of social services, particularly of health and education. It is complemented by the rights-based approach (RBA) to development, which considers social protection-articulated in some cases as "freedom from want"-as a human right and, hence, as a state obligation rather than a straightforward policy option (Barrientos and Hulme 2008).

With this framework, CCTs are understood and examined as programs that aim to realize human development, via the capability approach, and to fulfill people's right to social security and social protection or freedom from want.

\section{The Capability Approach, MDGs and CCTs}

The theoretical and conceptual foundations of CCT programs, and social protection policy in general, can be located in the capability approach to develop- 
ment. This approach, which is attributed to economist and philosopher Amartya Sen, presents an alternative to economistic development frameworks that focus on efficiency and effectiveness. The capability approach focuses on fostering human capabilities to address pressing problems of poverty and inequality (Clark 2005) and understands poverty as a deprivation of capability rather than a shortage of income.

In Development as Freedom, Amartya Sen's basic argument is for development to be assessed in terms of "the expansion of the 'capabilities' of people to lead the kind of lives they value-and have reason to value" (Sen 1999, 18). It argues against merely relying on straightforward measures of economic growth like gross domestic product (GDP) and gross national income (GNI) to determine national progress (which is equated to growth). Sen therefore, redefines economic developpment and challenges the Utility Approach to development, which focuses on the accumulation of resources (Anand et al. 2005; Clark 2005).

Human development, therefore, can be achieved through the provision of basic health, education and social services and facilities, all of which contribute to the expansion of people's capabilities and life choices. For Sen (1999), development occurs when people are free to actually realize their potential or are given opportunities to do so (Sen 1999).

The capability approach has been adopted widely by organizations seeking to pluralize the understanding of development to include health and education, for example, in measurable, evaluative and actionable terms (Alkire 2005; 2008). The United Nations Development Program (UNDP) and its Human Development Report (HDR) are well known. The capability approach has also influenced international development agendas and policies through the MDGs, with its focus on alleviating poverty and reducing vulnerability. The MDGs constitute a globally accepted "blueprint" agreement for international development. They are due for completion in 2015, a deadline which has pushed lagging countries like the Philippines to implement programs, such as CCTs, to fast-track MDG progress, particularly on Goal 1 (poverty and hunger) and Goal 2 (primary education) (Fernandez and Oflindo 2011).

In this assessment of Pantawid and Bolsa Familia, as CCT programs under a social protection policy framework, the relevant question is whether these programs focus solely on the demand-side constraints of social services or whether they are complemented by interventions on the supply-side. The capability approach provides that apart from short-term social protection measures like CCTs, social services and facilities must be made available to citizens.

\section{METHODS}

This paper employs qualitative research methods, specifically by reviewing 
documents and analyzing policies. Government documents on Pantawid and Bolsa Familia were secured to review the rationale, design and objectives of each program. Secondary data on national budgets were obtained from the World Bank Development Research Group's online database, which contains the most updated and comparable data sets on public expenditures on health and education. Government data sets directly from Brazil and the Philippines are not comparable or, in most cases, are not current. Data from UNESCO's EduStats database were also used, along with data on Human Development in Brazil and the Philippines from the UNDP.

\section{DISCUSSION AND ANALYSIS}

Figure 1 to Figure 9 show data on Brazil and the Philippines in terms of their public spending on health and education, and human development index values. These figures serve the purpose of graphically comparing both countries on the given terms in the same time period, which is inclusive of the introduction and implementation of their respective CCT programs.

Based on the study framework, these data are relevant in assessing, at least initially, whether CCT programs are being complemented by supply-side provisions, as measured by public health and education expenditures. Further explanations are provided as part of the discussions below. To reiterate, for Sen (1999), human development can be only be achieved when both the supply-side and the demand-side constraints of social services are addressed. Since CCT programs only address demand-side constraints, they should be complemented by ongoing public investments in health and education to address the supply-side constraints (UNDP 2013).

Government investments in basic social services like health and education are measured primarily by public expenditure or spending, as indicated in annual national government budgets. Importantly, all these efforts-CCTs and public expenditures-must be supported by an overarching policy that recognizes and treats education, health and social protection as human rights (Piron 2004; Sepulveda and Nyst 2012).

\section{Public Expenditures on Heath}

Figure 1 to Figure 4 are related to public spending on health services in Brazil and the Philippines. Unless otherwise stated, data from these charts were obtained from the World Bank Development Research Group's online database. ${ }^{2}$ The figures are used here to provide a broader understanding of public health expenditure trends in the two countries for an analysis of national social protection policies since the advent of the respective CCT programs. 
Figure 1 illustrates public spending on health as a percentage of gross domestic product (GDP) from the year 2000 to 2011. Public spending on health, as shown in the figure, consists of recurrent and capital spending from national and local government budgets, external loans and grants (including donations from international agencies and nongovernmental organizations), and social (or compulsory) health insurance funds.

In Brazil's case, public health expenditure as percentage of GDP increased from $2.9 \%$ in 2000 to a peak of $4.2 \%$ in 2010 . The overall trend shows a $25 \%$ increase from the baseline spending in 2000. The comparable data for the Philippines reveals considerable differences. From a starting figure of $1.5 \%$ in 2000 , public spending on health dropped to a low of approximately $1.1 \%$ in 2002 before a gradual increase to $1.5 \%$ in 2010 . The overall trend is flat across the period represented.

Figure 2 shows government spending on health in proportion to its total expenditures from 2000 to 2011. According to the World Bank, health expenditures cover health services (preventive and curative), including family planning and nutrition activities, and emergency aid designated for health. Water and sanitation provisions and activities are not included.

In 2000, the Philippine government spent $7.02 \%$ of its total expenditures on health. This was higher than Brazil's 4.08\%. However, this declined to 5.04\% in 2002 before increasing to reach $7.33 \%$ in 2006 . Health spending again dipped before reaching $7.55 \%$ in 2010 . On the other hand, Brazil's health expenditure proportionate to total government expenditure increased steadily from 2000. By 2011, Brazil was spending $8.69 \%$ of total government expenditure on health ( $110 \%$ above the 2000 figure).

Figure 3 shows health expenditure per capita of Brazil and the Philippines in international dollars converted using 2005 purchasing power parity (PPP) rates. Health expenditure per capita is the sum of public and private health expenditures as a ratio of total population. It covers health services (preventive and curative), including family planning and nutrition activities, and emergency aid designated for health. However, it excludes activities and provisions related to water and sanitation. Data show that, overall, from 2000 to 2011, Brazilians spent at least six times more on health expenses than did Filipinos. Similarly to Figure 1, the trend for Brazilians' health expenditures from 2000 to 2011 shows a steady increase. The baseline figure presented is 494 international dollars in 2000. In 2005, it increased to 695 international dollars. By 2011, it had nearly doubled to 1,043 international dollars. By comparison, Filipinos' expenditures on health barely doubled from 2000 (79 international \$) to 2011 (169 international \$). Finally, Figure 4 shows the percentage of public health expenditures relative to total health expenditures. It shows the government's share in Brazilians' and Filipinos' total health expenditures from 2000 to 2011. 
Data show that, over a period of 11 years, the Brazilian government has paid for at least $40 \%$ of Brazil's total health expenditures. Its share in total health expenditures peaked at $47 \%$ in 2004 and 2010. By comparison, the Philippine government's share in total health expenditures has steadily decreased since 2000 (from a peak of $47.6 \%$ in 2000 to a low of $32.4 \%$ in 2008). By 2011, the state's contribution was $33 \%$.

\section{(1) Analysis}

The 1987 Philippine Constitution recognizes the people's right to affordable healthcare. However, as Figure 1 to Figure 4 show, in the last decade, the Philippine government has been spending less and less on health, especially when compared to the Brazilian government's spending. Philippine spending on health as a percentage of GDP ranked 169th in the world in 2009 (WHO-DOH 2012). Its low and flat spending on health, as percentage of GDP and total government expenditures-even after the introduction of Pantawid in 2007-is far removed from international standards and, arguably, suggests that increasing equitable access to health services and improving health outcomes of the population is not the government's long-term priority. It further suggests a policy bias towards privatizing health services in the country.

According to a report by the World Health Organization (2011), two of the most pressing problems of the Philippine health care system are related to financing and physical and human resources. As regards financing, the Philippine health care system is beset by extremely high levels of out-of-pocket payments (WHO, 2011). Out-of-pocket costs, particularly on medicines, increased from $47 \%$ to $57 \%$ between 1997 and 2007 (WHO-DOH 2012). While the Philippines has a national health insurance agency (PhilHealth), the financial protection it guarantees is very limited (WHO 2011). Also, private sector health care provision is both highly visible and openly promoted by the state, and covers some $30 \%$ of the population (WHO-DOH 2012). Public health care provision thus largely caters to the poor and extremely poor.

In terms of physical and human resources, the Philippines continues to experience a shortage of public healthcare facilities and trained medical staff, particularly in rural areas (WHO 2011). Of the country's 1,800 hospitals, less than $50 \%$ (or 791) are public (WHO-DOH 2012). In 2011, the Philippines had 10,773 accredited general medical practitioners and 12,701 medical specialists, roughly 1.15 per 1,000 citizens (WHO-DOH 2012). This complex phenomenon is extenuated by the fact that many health care trainees study specifically in order to emigrate, which is a factor in the low incidence of accredited health care professionals in non-urban areas of the country (WHO-DOH 2012). In 2010, the Aquino government introduced a reformed health care initiative, known as The Aquino Health 
Agenda: Achieving Universal Health Care for all Filipinos. It is as yet too early to evaluate the success of the initiative or whether it includes specific measures to address structural problems in the health care system by increasing public expenditures on health. However, it is notable that the pressing problems of financing and physical resources remain outside the reach of the Pantawid, which focuses on decreasing maternal and infant mortality and improving children's health outcomes.

The conditions in the Philippines differ markedly from Brazil's. First, Brazil's spending on health as a percentage of GDP ranked 44th in the world in 2009. Second, Brazil had 1.7 doctors per 1,000 citizens in 2007, a ratio that increased to 1.8 to 1,000 by 2010 (World Bank 2013). Thirdly, according to Mendes (2012) and Paim (2011), among others, the National Health Policy, organized around the Unified Health System (SUS), guarantees Brazilians' right to health care. The SUS is constituted around universal access, equity, decentralized control and operations, participatory governance, and funding split among cities, states, and the federal government. Aligned with the goals of Bolsa Familia, since 2006, the Brazilian "Health Pact" assures commitments are fulfilled on the basis of mutual responsibilities and targets. Since the SUS followed from Brazil's post-dictatorship constitutional change, its philosophy and conceptualization incorporated universality, equity and citizens' rights. As a result, access to primary health care increased by 450\% between 1981 and 2008 (Mendes 2012).

In summary, the chronically low spending on health by the Philippine government is being borne mostly by the poor and very poor, who are dependent on state subsidies coursed through public hospitals and, for some, on Pantawid cash grants. While Pantawid aims to improve maternal and child health outcomes among the very poor, it is not being supplemented by sustained and/or strategic increases in public health expenditures to answer supply-side constraints in the Philippine health care system. In contrast, the Brazilian government appears to be more guided in seriously addressing gaps in its health care system through sustained increases in public health expenditures alongside its introduction of Bolsa Familia. The Brazilian health care system is far from ideal and work remains to be done to realize universal access to health care, yet the trends reflected in the charts suggest that in this analysis the government is on a deliberate path towards sustainably improving the people's overall health outcomes.

\section{Public Expenditures on Education}

Figure 5 and Figure 6 detail public spending on education as a percentage of GDP and total government expenditures between 2000 and 2010 in Brazil and the Philippines. According to the World Bank, public spending on education consists of current and capital public expenditures, including government spending on 
educational institutions (both public and private), national and local education administration, and subsidies for private entities (students and households).

Figure 5 shows that, in Brazil's case, education expenditures as a percentage of GDP began at $4 \%$ in 2000. There was a slight decrease between 2001 and 2002, before beginning a substantial and sustained increase from 2003. Notably, the incorporation of the Bolsa Familia program began in 2003. By 2010, public spending on education in Brazil had reached nearly 6\% of GDP, which is the international benchmark set by the Delors Commission. Overall, this amounted to an increase of over $30 \%$ in government spending on education since 2000 . The trend line in the graph indicates an upward trend.

The corresponding data from the Philippines both begins from a lower level (3.27\%) in 2000 and decreases further (2.43\%) in 2005. In marked contrast to Brazil's upward trend, the 2009 rate for the Philippines is $2.65 \%$, the last year for which the World Bank data is available.

Figure 6 shows public spending as percentage of total government expenditure from 2000 to 2010. From 2000 to 2006, the Philippine government spent more on education as a percentage of its total expenditures than Brazil did. In 2000 , the figure was $13.95 \%$ of total expenditure, while Brazil spent $12.01 \%$. By 2002, the Philippine government was spending 17.79\% against Brazil's 10.8\%. A shift, however, occurred in 2007 when Brazil began outspending the Philippines in terms of education expenditures as a percentage of total expenditures $(16.1 \%$ against $15.88 \%$ ).

Notably, from 2004, the share of education in Brazil's government expenditures began a sustained increase, reaching $17.43 \%$ in 2008 and $18.1 \%$ in 2010 . The overall trend, thus, shows increasing public investment in education, particularly since 2004. By comparison, the trend line of the Philippine government's expenditures on education as a percentage of total expenditures, which dipped to $15.05 \%$ in 2009 , shows a much slighter incline, thus suggesting little to no real change in overcoming the prevailing structural deficits in supply-side provisions for education.

Figure 7 and Figure 8 pertain to public education expenditure per primary and secondary student in Brazil and the Philippines from 2000 to 2009. The figures are expressed in terms of the percentage of GDP per capita. Public education expenditures per student is the current public spending on education divided by the total number of students by level-in this case, primary and secondary, as a percentage of GDP per capita. Public education expenditures include current and capital government spending on educational institutions (public and private), education administration, as well as subsidies for students and households.

Overall, the trends in public education spending per primary and secondary student in Brazil and the Philippines reveal large contrasts. For public spending per primary student (Figure 7), data for Brazil show a relatively sharp and steady 
increase from $10.7 \%$ of GDP per capita in 2000 to $20.5 \%$ in 2009 . Data for the Philippines show a decline from $11.97 \%$ of GDP per capita in 2000 to $8.98 \%$ in 2009.

Data on public spending per secondary student follows the same contrasting trend (Figure 8). The Brazilian government spent $10.42 \%$ of GDP per capita on every secondary student in 2000 , a figure which almost had doubled to $20.87 \%$ by 2008. The increase is steady and sustained year by year. The Philippine government, however, spent $10.23 \%$ of GDP per capita on every secondary student in 2000 . At $9.12 \%$ in 2008 , spending had decreased.

\section{(1) Analysis}

The Philippine government is obliged by the 1987 Constitution to ensure accessible quality basic education for all and provide the highest budgetary priority to education (Article XIV, Sec. 5, par. 5). Filipinos' right to quality basic education is further substantiated in Republic Act 9155 ("Governance of Basic Education Act of 2001") and the Republic Act 6655 ("Free Secondary Education Act"). The Philippine government is also committed to the "Education for All" (EFA) 2015 agenda and the Millennium Declaration. The goals of both these international agreements are included in the Medium-Term Philippine Development Plan (2004-2010), Part IV of which focuses on education.

For Brazil, its Federal Constitution (Title VIII, Chapter III, Sec. 1) also guarantees people's right to high-quality education. Article 205 states that education is "the right of all and duty of both the State and families, in cooperation with general society," while Article 213 provides that "public resources will be allocated to schools and other community, religious or philanthropic schools that channel funds to education, scholarships, or research."

However, despite these explicit policy statements, trends shown in Figures 5 to 8 suggest that the government of Brazil, to a greater extent than the Philippine government, is consistently following through on its commitments by investing in public education. As a 2011 report by the Organization for Economic Cooperation and Development (OECD) stated, between 2000 and 2008, expenditure per student (primary and secondary) in Brazil increased by $121 \%$. In the same period, the expenditure per student in the Philippines decreased by about $25 \%$ for the primary level and by $10 \%$ for the secondary level.

Brazil's policies in this period shed light on its increased investment in education. Under the presidency of Fernando Henrique Cardoso (1995-2003), three national education policies were prioritized to address the gaps in the country's education system: education finance equalization to redistribute education resources and establish an education spending floor per student; conditional cash transfers to enable the poorest families to send their children to school (i.e., Bolsa Escola, and 
later Bolsa Familia); and introducing standardized educational measurements to improve national assessments and planning for education (i.e., Prova Brasil and the National Assessment of Basic Education) (World Bank 2010).

Under President Lula da Silva, Brazil instituted its Plano de Desenvolvimento da Educação (PDE) or Education Development Plan in 2007. The PDE's principal aims include promoting universal high-quality basic education, furthering science and technology research, and hiring qualified personnel throughout the education system. The PDE has been supported by yearly increases in education funds (as shown in Figures 5 to 8). This commitment corresponds with and complements the expansion and targeting of the ongoing Bolsa Familia program.

The case of the Philippines presents a sharp contrast. The Philippine education sector faces serious problems on both the supply and demand sides. Overcrowded classrooms, lack of textbooks and other proper teaching materials, along with the high dropout rates and stagnant participation rates, particularly in seconddary education, are perennial issues. In 1991, the government formed the Congressional Commission on Education (EDCOM) to address chronic problems like shortages of classrooms, textbooks and teachers. EDCOM was followed up by the Philippines Education Sector Survey (PESS) in 1998 and the Presidential Commission on Educational Reform (PCER) in 2000. However, these efforts have produced no real outcomes in terms of students' performance (World Bank 2013). Such problems are rooted in the insufficient funds given to education each year, a high population growth rate, a lack of political support, and a weak institutional environment for genuine educational reforms (World Bank 2013).

In summary, while both governments recognize people's right to high quality basic education, the government of Brazil has been progressively investing in the sector through different means such as increasing expenditures in basic education, enacting social protection programs on education, and improving monitoring and evaluation mechanisms. Consequently, it has seen improvements in student participation and attainment levels in secondary education (OECD 2011). Importantly for Brazil, its spending is guided by a foundational education policy and development plan aimed at addressing inequalities and giving opportunities to the country's poor. The Philippines, on the other hand, has been investing less and less in basic education over the last decade (excluding investments in the new $\mathrm{K}$ to 12 program). Until 2013, it has likewise lacked a coherent national education policy to seriously address perennial structural problems.

\section{Human Development}

Figure 9 shows the differences between Brazil and the Philippines with respect to Human Development Index (HDI) values. HDI accounts for three social dimensions: living standards, education, and health. These dimensions are, in turn, deter- 
mined by the following indicators: life expectancy, educational attainment (mean versus expected years of schooling), and gross national income per capita in each country (UNDP 1990). Sen (1999), as discussed in the study framework, recognizes that increasing public investment in social services is crucial to improving human development outcomes.

Figure 9 condenses data from 1980 to 2000 before showing the changes between 2005 and 2012. Brazil's standing in the index begins at 0.53 on the scale and had risen to 0.67 by 2000 . Thereafter, improvement is steady, reaching 0.73 (rank $88^{\text {th }}$, high human development) by 2012. In the case of the Philippines, the index begins at 0.57 in the $1980 \mathrm{~s}$ and grows at a slower rate to stand at 0.65 (rank $114^{\text {th }}$, medium human development) in 2012, a standing that Brazil surpassed in the 1990s.

Of principal interest is that Brazil began at a lower starting point than the Philippines in 1980, when each country was respectively ruled under conditions of martial law. Both countries adopted democratic constitutional change at roughly the same time (Brazil in 1988, the Philippines in 1987). However, Brazil prioritized the issue of equitable provision of social protection soon after its constitutional change; consequently implementing social protection initiatives that coalesced into the Bolsa Familia program by 2003, with sustained complementary frameworks for development of the health and education sectors. The Philippines, by contrast, not only lags behind Brazil's HDI achievements, but did not appear to prioritize, at least according to its national budget over time, the fulfillment of the rights and capabilities of the nation's citizens. The introduction of its CCT program in 2007 , therefore, stands out as a sole effort that has yet to be fully integrated with other efforts to fulfill people's rights to social protection.

\section{CONCLUSION}

Although conditional CCT programs represent only one among many social policy options a government can choose to address social inequalities, reduce extreme and chronic poverty, and ultimately, achieve human development, they have been promoted by major international development institutions as an especially innovative element in the portfolio of social protection measures in the Global South. However, whereas the original CCT programs of Brazil and Mexico were initiated to counter the social costs of structural adjustment in the 1980s, CCT programs today, like the Philippines' Pantawid, have been and continue to be implemented mainly to support the achievement of specific MDGs by 2015 . Furthermore, unlike earlier initiatives which depended more on the advice of local experts and domestic funding, CCT programs heavily rely on the technical expertise and funding from international financial institutions led by the World Bank. They have become, as Adesina (2010) phrased it, "diminutive" versions of 
what was originally a major social policy.

The data presented in this paper show that from the comprehensive commitment of Brazil to its CCT program in 2003, supply-side commitments in the sectors of health and education showed absolute, not merely relative, improvements. The Brazilian government, particularly but not exclusively under former President Lula da Silva (see Hall 2006), thus appears to be seriously committed to arresting intergenerational poverty and reversing the exclusion of the poorest sectors of Brazilian society, with Bolsa Familia as just one intervention.

In the case of the Philippines, since 2000 and even after the introduction of Pantawid in 2007, spending on health and education remained flat or in relative decline. Additionally, there has been no comprehensive social development policy or any specific policy pertinent to health and education in place to guide public expenditures on health and education. In fact, the Philippine government appears to be relying solely on Pantawid to solve extreme poverty and trickle-down the benefits of its growing economy.

\section{Patchwork vs Proactive Social Policy}

Pantawid, therefore, qualifies as an "add-on" social policy that meets World Bank conditions and electoral-cycle peculiarities (that is, political utility) without addressing in a comprehensive and path-breaking way the fundamentals of poverty reduction that are the purpose of its implementation. Brazil's Bolsa Familia, conversely, is but one intervention in place to achieve human development and address extreme poverty.

The Philippine government is motivated to meet MDG goals of reducing extreme poverty, improving maternal and child health, and sending all children to school by 2015 . Yet, as it currently operates, it expects to do this mainly through a CCT program, and not by allotting sufficient public funds for social services. While the present government has in place different policies and programs (including Pantawid) that compel and guide it in fulfilling its constitutional role to provide affordable and high-quality health and education services, these have yet to translate to actual investment in public education and health services. What exists, therefore, are ad hoc patches of social protection programs and social policies that function unrelated to one another based primarily on the priorities of donor/lender organizations.

Brazil, by contrast, operates as a "proactive developmental state" (UNDP 2013, 4), which the 2013 Human Development Report describes as "a strong, proactive and responsible state [that] develops policies for both public and private sectors-based on a long-term vision and leadership, shared norms and values, and rules and institutions that build trust and cohesion." Such states as Brazil focus on people's needs, promote opportunities while protecting them from external and 
internal economic shocks, and consider investment in people's capabilities (through health and education) "not an appendage of the growth process but an integral part of it" (UNDP 2013, 4). Importantly, a proactive state practices "determined social policy innovation"-it does not pit economic growth and social or human development against each other, it explores different avenues applicable in their contexts to effectively reduce poverty (UNDP 2013, 5). It is not a coincidence that CCT programs were first "invented" in Latin America, as Britto (2005) argued, because states like Brazil have developed-and continue to develop-an agenda to expand poor people's choices by building their assets so as to allow them to productively participate in the growth of the economy. This, at least up until 2013, presents a sharp contrast to the "anti-developmental state" (Bello 2005) of the Philippines.

\section{REFERENCES}

Adesina, Jimi. 2010. Rethinking the Social Protection Paradigm: Social Policy in Africa's Development. Promoting Resilience Through Social Protection in Sub-Saharan Africa (2-22). Dakar: European Union/European University Institute.

Alkire, Sabine. 2008. Choosing Dimensions: the Capability Approach and Multidimensional Poverty. Retrieved from Munich Personal RePEc Archive: http:// mpra.ub.uni-muenchen.de/8862.

Alkire, Sabine. 2005. Valuing Freedoms: Sen's Capability Approach and Poverty Reduction. Oxford: Oxford University Press.

Anand, P., G. Hunter, and R. Smith. 2005. Capabilities and Well-Being: Evidence based on the Sen-Nussbaum Approach to Welfare. Social Indicators Research 74(1): 9-55. Springer.

Barrientos, Armando and David Hulme. 2008. Social protection for the poor and poorest in developing countries: Reflections on a quiet revolution (BWPI Working Paper 30). Manchester: Brooks World Poverty Institute.

Bassett, Lucy. 2008. Can Conditional Cash Transfer Programs Play a Greater Role in Reducing Child Undernutrition? Discussion Paper No. 0835. Washington, D.C: The World Bank.

Bello, Walden. 2009. The Anti-Development State: the political economy of permanent crisis in the Philippines. Manila: Anvil.

Bradshaw, S. 2008. From structural adjustment to social adjustment: A gendered analysis of conditional cash transfer programmes in Mexico and Nicaragua. Global Social Policy 8(2):188-207.

Britto, Tatiana. 2005. Recent trends in the development agenda of Latin America: an analysis of conditional cash transfers. Brasilia: Ministry of Social Development.

Clark, D. A. 2005. Sen's Capability Approach and the Many Spaces of Human 
Well-Being. Journal of Development Studies 41(8), 1339-1368.

Cook, Sarah and Naila Kabeer. 2009. Socio-economic security over the life course: A global review of social protection. Brighton: Institute of Development Studies.

Curry, M. S., A. Cadiogan, and R. Guigliano. 2013. Brazil's Bolsa Familia and the Philippines' '4Ps' CCT Programs: Considering South-South Cooperation for Social Policy Formulation and Poverty Reduction. Asia Pacific Social Science Review 13(1): 1-15.

Department of Social Welfare and Development of the Philippines (DSWD). 2009a. Conditional Cash Transfer (CCT) Philippines-Improving the Human Capital of the Poor (Pantawid Pamilyang Pilipino Program or 4Ps). 4Ps Concept Paper for MCC published on 21 January 2009.

Department of Social Welfare and Development of the Philippines (DSWD). 2009b. 4Ps: Building Human Capital for Social Resiliency. Quezon City: DSWD.

De Janvry, Alain, Elisabeth Sadoulet, Pantelis Solomon, and Renos Vakis. 2006. Uninsured Risk and Asset Protection: Can Conditional Cash Transfer Programs Serve as Safety Nets? Washington, D.C: The World Bank.

De la Brière, Benedicte and Laura Rawlings. 2006. Examining Conditional Cash Transfer Programs: A Role for Increased Social Inclusion? Washington, D.C: The World Bank.

Drèze, Jean and Amartya Sen. 2011. Putting Growth in its Place. Retrieved on 26 October, 2012 from http://www.outlookindia.com/article.aspx?27884.

Fajth, Gaspar and Claudia Vinay. 2010. Conditional Cash Transfers: a Global Perspective. UNDP. Retrieved on 28 October, 2012 from http://mdgpolicynet. undg.org/ext/MDG_Insight/MDG_Insights_Feb_2010.pdf.

Farrington, John, Paul Harvey, and Rachel Slater. 2005. Cash Transfers in the Context of Pro-Poor Growth. Eschborn: GTZ.

Fernandez, Luisa and Rosechin Olfindo. 2011. Overview of the Philippines' Conditional Cash Transfer Program: the PantawidPamilya Pilipino Program (Pantawid Pamilya). Manila: The World Bank Office.

Fiszbein, Ariel, andNorbert Schady. 2009. Conditional cash transfers: Reducing present and future poverty. Washington D.C.: The World Bank.

Hall, A. 2006. From Fome Zero to Bolsa Familia: Social Policies and Poverty Alleviation under Lula. Journal of Latin American Studies 38(4): 689-709.

Hall, A. 2007. Social policies at the World bank: paradigms and challenges. Global Social Policy 7(2): 151-175.

Handa, S. and Davis, B. 2006. The Experience of Conditional Cash Transfers in Latin America and the Caribbean. Development Policy Review 24(5): 513536.

Holzmann, Robert, Lynne Sherburne-Benz, and Emil Tesliuc. 2003. Social risk management: the World Bank's approach to social protection in a globalizing 
world. Washington D.C.: The World Bank.

Lomelí, E. V. 2008. Conditional cash transfers as social policy in Latin America: an assessment of their contributions and limitations. Annual Review of Sociology 34(1): 475-499.

Mendes, M. E. 2012. Brazil: The Country, Its Healthcare and Clinical Pathology. Johns Hopkins Pathology. Retrieved on August 11, 2014 from http://apps. pathology.jhu.edu/blogs/pathology/pathology-in-brazil.

Pacheco Santos, L. M., R. Paes-Sousa, E. Miazagi, T. Silva, and A. Medeiros da Fonseca. 2011. The Brazilian experience with conditional cash transfers: A successful way to reduce inequity and to improve health. Paper presented at the World Conference on Social Determinants of Health, Rio de Janeiro, Brazil.

Paim, J., Travassos, C., Almeida, C., Bahia, L., and Macinko, J. 2011. The Brazilian health system: history, advances, and challenges. The Lancet, 377: 1778-1797.

Piron, Laura-Helene. 2004. Rights Based Approaches to Social Protection. London: Overseas Development Institute.

Rawlings, Laura B. and Gloria M. Rubio. 2005. Evaluating the Impact of Conditional Cash Transfer Programs. Washington, D.C: Oxford University Press/ The World Bank.

Sen, Amartya K. 1999. Development as Freedom. New Delhi: Oxford University Press.

Sen, A. K. 2000. A Decade of Human Development. Journal of Human Development 1(1): 17-23.

Sepulveda, Magdalena and Carly Nyst. 2012. The Human Rights Approach to Social Protection. Helsinki: The Ministry of Foreign Affairs of Finland.

SEPO (Senate Economic Planning Office). 2011. K to 12: The Key to Quality Education? SEPO Policy Brief 11-02. Retrieved from https://www.senate.gov.ph/ publications/PB\%202011-02\%20-\%20K\%20to\%2012\%20The\%20Key\%20 to $\% 20$ Quality.pdf.

Tabor, Steven R. 2002. Assisting the Poor with Cash: Design and Implementation of Social Transfer Programs. New York: The World Bank.

UNDP (United Nations Development Programme). 1990. Human Development Report 1990-Concept and Measure of Human Development. Retrieved from http://hdr.undp.org/sites/default/files/reports/219/hdr_1990_en_complete_nos tats.pdf.

UNDP (United Nations Development Programme). 2013. Human Development Report 2013-The Rise of the South: Progress in a Diverse World. Retrieved from http://hdr.undp.org/sites/default/files/reports/14/hdr2013_en_complete. pdf.

Vermehren, Andrea. 2003. Conditional cash transfer programs: an effective tool for 
reaching the poorest and most vulnerable. In Volatility, risk, and innovation: Social protection in Latin America and the Caribbean (49-53), eds. Ana Maria Arriagada and Robert Holzmann. Washington, D.C.: The World Bank.

World Bank, The. 2010. Achieving World Class Education in Brazil: The Next Agenda. Retrieved from www.iepecdg.com.br/uploads/livros/1012achieving world.pdf.

World Bank, The. 2012. Resilience, Equity, and Opportunity. The World Bank 2012-2022 Social Protection and Labor Strategy. Retrieved from http://sitere sources.worldbank.org/SOCIALPROTECTION/Resources/280558-1274453 001167/7089867-1279223745454/7253917-1291314603217/SPL_Strategy_ 2012-22_FINAL.pdf.

World Bank, The. 2013. Philippines Education Policy Notes. Retrieved from http:// siteresources.worldbank.org\%2FINTPHILIPPINES\%2FResources\%2FDB18 -EducationPolicyNote-July13.pdf.

World Health Organization. 2011. The Philippines Health System Review. Health Systems in Transition 1(2). 


\section{Appendix}

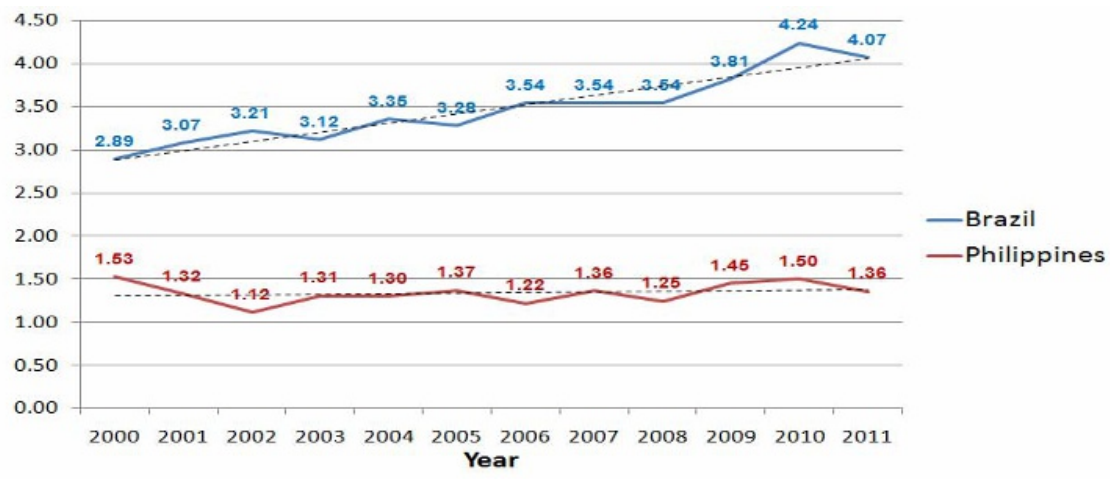

SOURCE: World Bank.

Figure 1. Public SPEnding on Health in BraZIL and the PhilipPines(\% OF GDP)

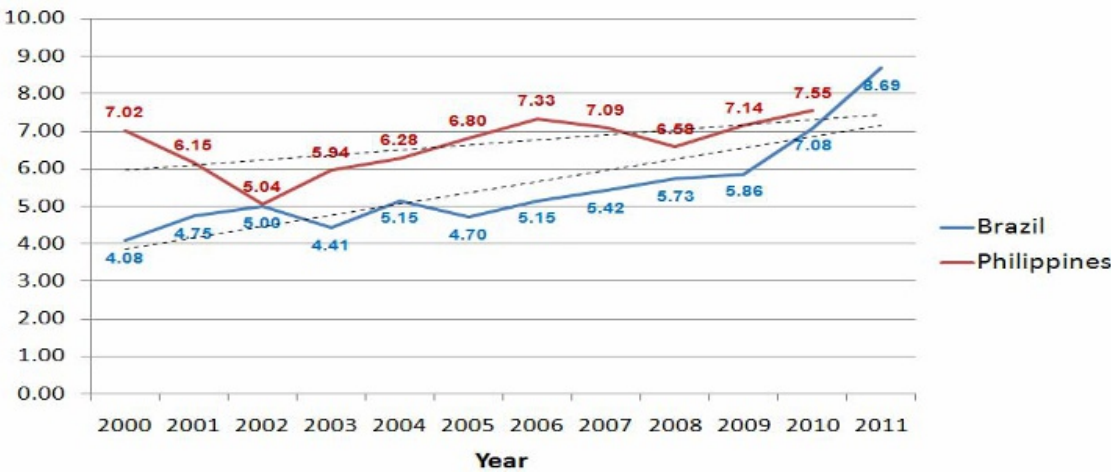

SOURCE: World Bank.

Figure 2. Public Spending On Health in BRAZIL AND the PhilipPines (\% OF GOVERNMENT EXPENDITURE)

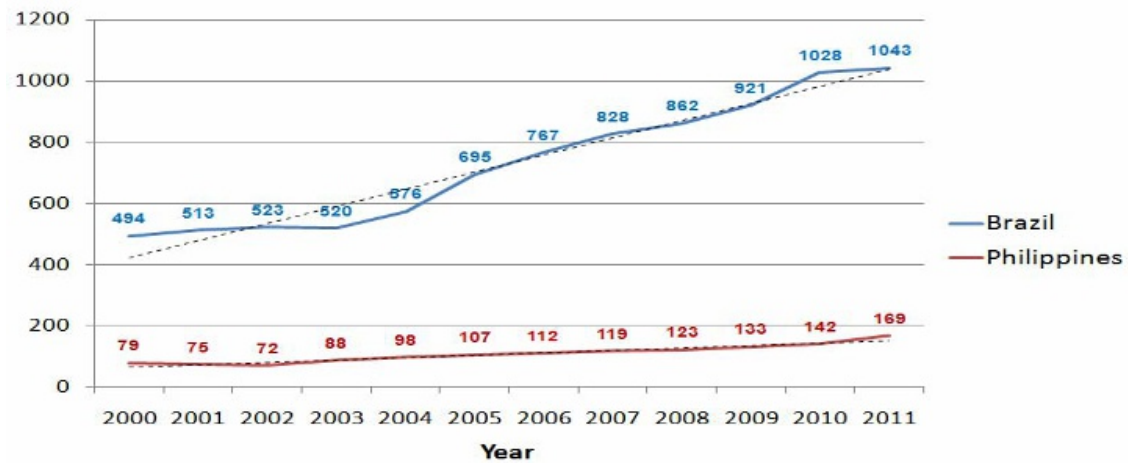

SOURCE: World Bank.

Figure 3. HeAlth EXPENDITURE PER CAPITA In BRAZIL AND THE PHILIPPINES (PPP) (CONSTANT 2005 INTERNATIONAL \$) 


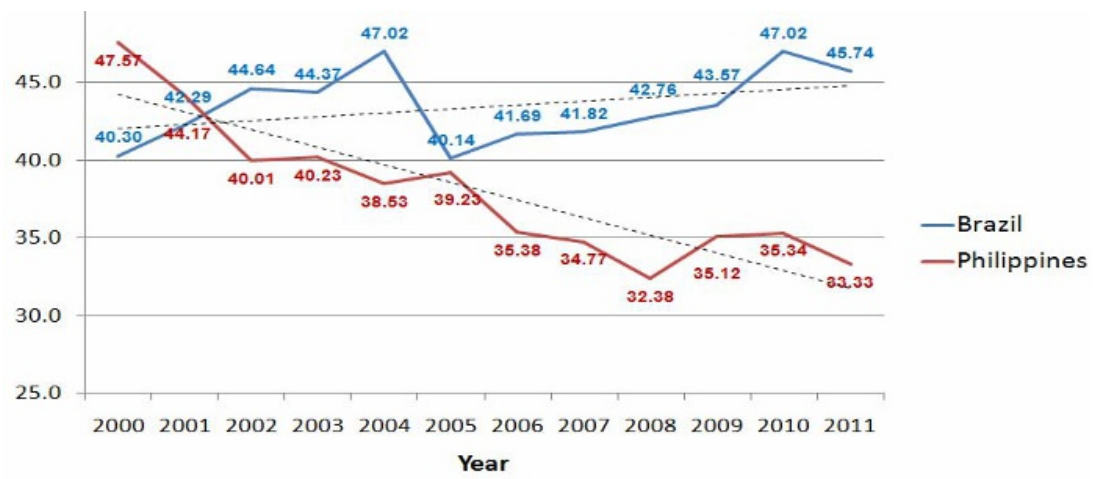

SOURCE: World Bank.

Figure 4. Public Health Expenditure in BraziL AND the Philippines (\% OF TOTAL HEALTH EXPENDITURE)

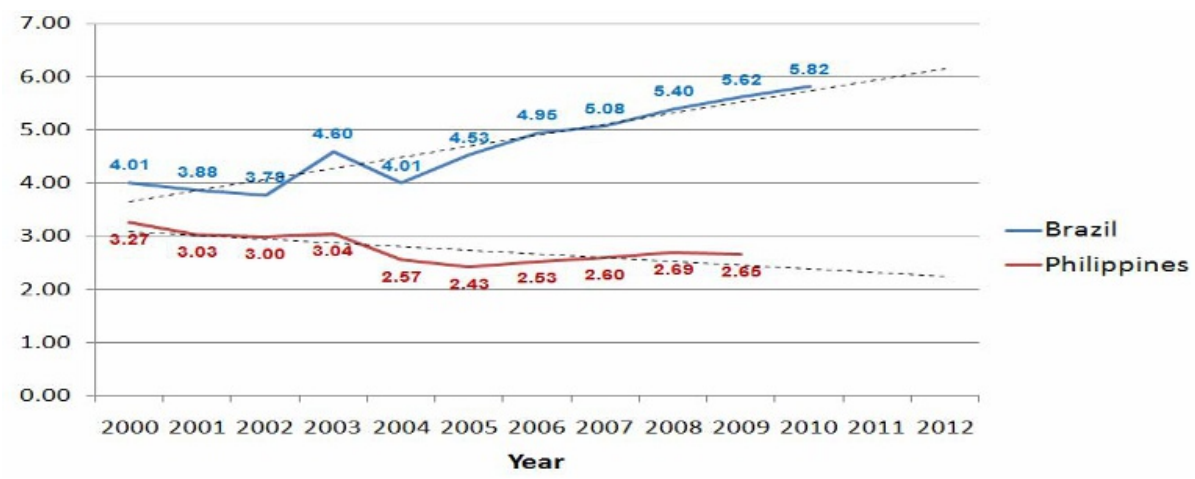

SOURCE: UNESCO.

Figure 5. Public SPENDing On EdUCATION In BRAZIL AND the PhILIPPINES (\% OF GDP)

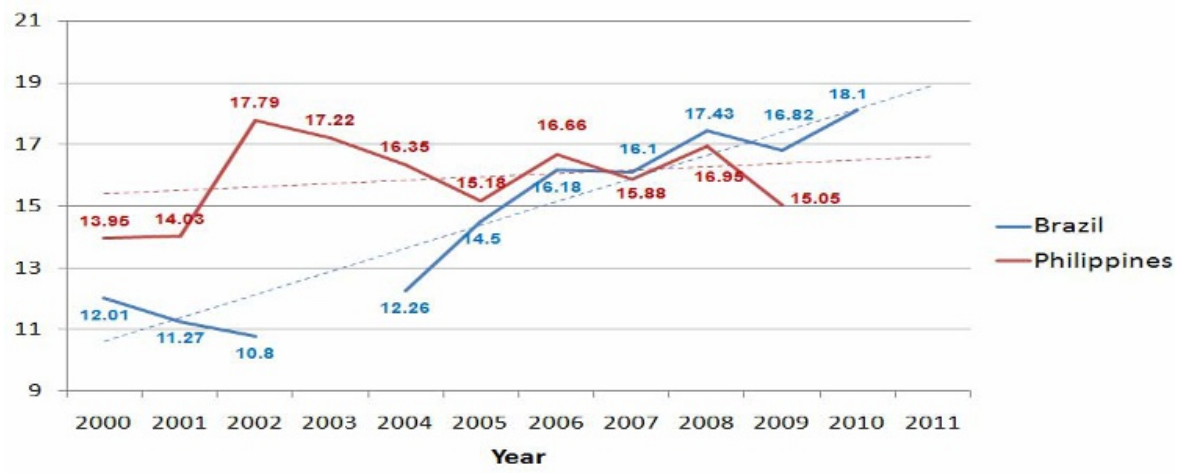

SOURCE: World Bank.

Figure 6. Public Spending on Education in BRAZIL AND the Philippines (\% OF GOVERNMENT EXPENDITURE) 


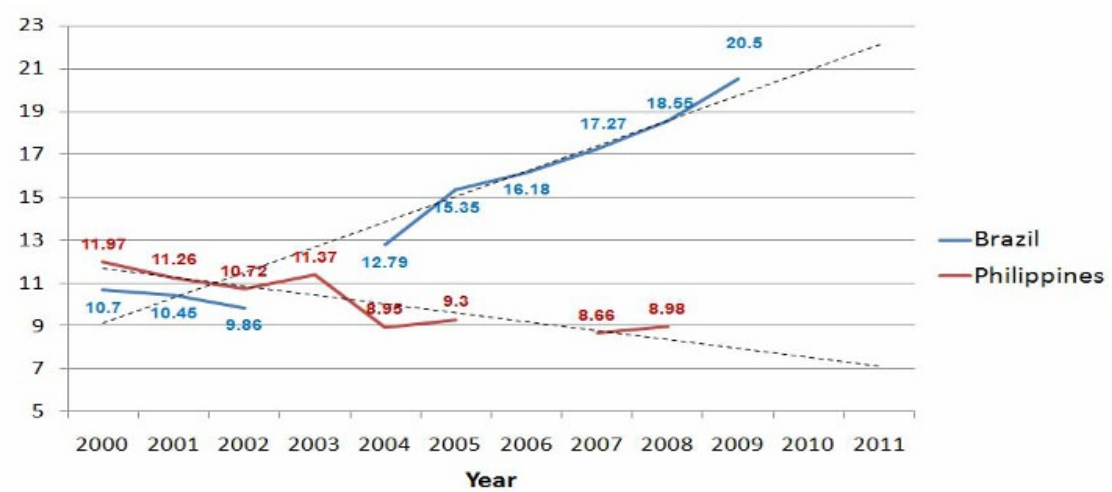

SOURCE: World Bank.

Figure 7. Public Education EXPENDiture PER PRimary STUdENT IN BRAZIL AND THE PHILIPPINES (\% OF GDP PER CAPITA)

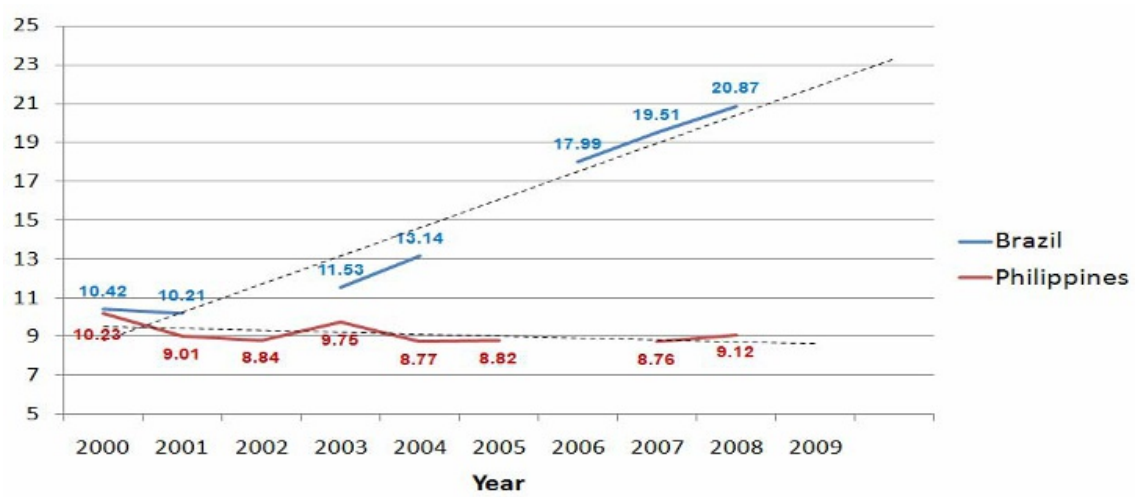

SOURCE: World Bank.

Figure 8. PUblic EduCATION EXPENDITURE PER SECONDARY STUdENT IN BRAZIL AND THE PHILIPPINES (\% OF GDP PER CAPITA)

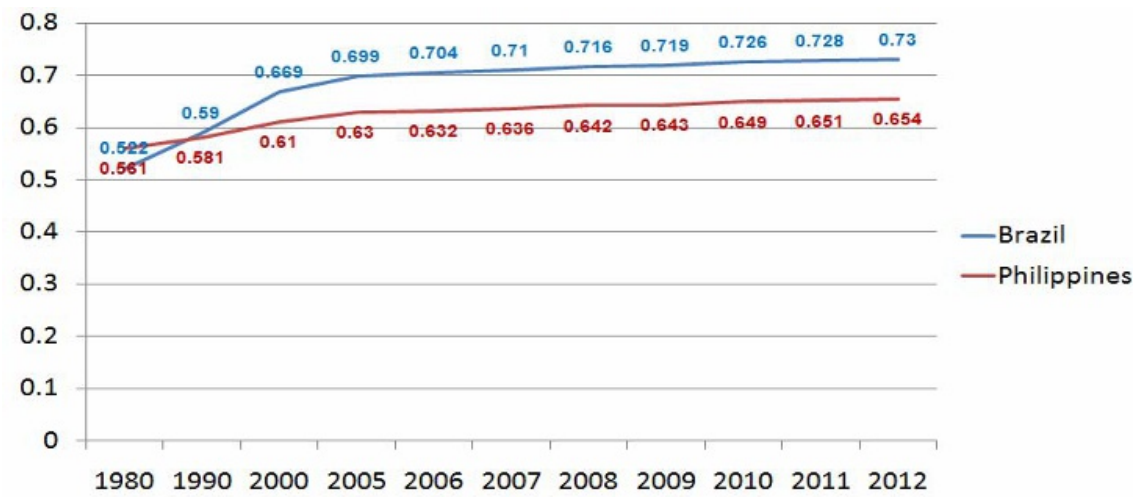

SOURCE: UNDP.

Figure 9. Human Development Index (HDI) Values, BRAZIL AND the PhilipPines 


\section{ENDNOTES}

1 A document prepared by the Philippine Department of Social Welfare and Development (DSWD, 2009b) specifically cited the success of Brazil's Bolsa Familia CCT program when it argued for the continuation of Pantawid until 2014.

2 http://data.worldbank.org/ (last accessed July 1, 2014). 